\title{
Electronic Payment Systems Implementation and the Performance of Commercial Banks in Nigeria
}

\author{
Bingilar Paymaster Frank and Bariweni Binaebi
}

\begin{abstract}
This research paper investigated the effect of electronic payment systems on the performance of commercial banks in Nigeria. For the purpose of the study, data was collected from secondary sources specifically from the CBN statistical bulletin and comprised of data on the assets base of commercial banks and internet banking (ATM, POS, Internet banking and Mobile banking) for the period of 2009 to 2019. The collected data was analyzed using ordinary least square (OLS) regression technique. Findings of the research showed that there is a statistically significant positive relationship between ATM transactions and the assets base of commercial banks in Nigeria. Internet (online) banking transactions had a positive relationship with the asset base of commercial banks. There is a positive and statistically significant relationship between mobile banking transactions and the assets base of commercial banks. However, Point of Sales (POS) transactions had a negative statistical relationship with the asset base of banks. From the findings of the study, It is concluded that implementation of electronic payment system in banks have had mixed effect on the performance of banks. Thus, while ATM, internet banking and mobile banking leads to improvements in the performance of banks, same cannot be said for point of sales machines which has a negative effect on bank performance. Based on the above, it is recommended that commercial banks increase investments in the implementation of electronic payment systems. Finally, it is recommended that the government improve on internet infrastructure in order to capture the rural areas in order to promote financial inclusion through electronic banking in the country.
\end{abstract}

Index Terms - Internet banking, mobile banking, electronic payment system, bank performance, electronic banking.

\section{INTRODUCTION}

For most of the past decade and half, commercial banks in Nigeria have been at the forefront of adopting the use of information and communication technology in banking business. This has for the most part been accompanied by the increased use of electronic payment systems in the country. From the use of Automated Teller Machine (ATM), Point of Sales (POS) machines, Internet (online) banking services and Mobile banking transactions, the Nigeria banking industry has witnessed a phenomenal growth in the use electronic banking channels. These has been credited with numerous advantages including the reduction in the associated costs and risks inherent in cash based banking

Published on October 11, 2019.

Bingilar Paymaster Frank is with Department of Accountancy, Faculty of Management Sciences, Niger Delta University, Wilberforce Island, Bayelsa State, Nigeria.

Bariweni Bineabi is with the Department of Business Education, School of Vocational and Technical Education, Isaac Jasper Boro College of Education, Sagbama, Bayelsa State Nigeria

(e-mail: bbinaebi2@gmail.com). transactions. Furthermore, the use of electronic banking systems also reduces the rates of errors in transactions, makes the tracking of specific transactions much easier in addition to increasing the speed of complete transaction in real-time not minding the distance between parties to the transaction (Kelvin, 2012; Tijani \& Ilugbemi, 2015).

In spite of the attendant challenges, electronic banking transactions has been favorably reviewed in Nigeria. This can be attested by the consistent rise in electronic banking activities over the years. The Central Bank of Nigeria (CBN) statistical bulletin (2019) shows that the volume of transactions using Automated Telller Machines (ATM) increased from 109.162 million transactions in 2009 to 373.488 million in 2012. This represents about 244\% increase in just over a period of three years. The bulletin also reports increase of volume to 875.52 million transactions in 2018 from indicating a 702\% increase over the period of ten years (2009 to 2018). In the same vein, the use of POS has also recorded significant growth over time from 0.918 million transactions in 2009 to 295.89 million transactions by 2018 - a growth of over $32000 \%$ over the period. The use of mobile pay has grown by over $4700 \%$ for the period under review from 1.81 million transactions in 2009 to 87.1 million transactions in 2018. In contrast, the use of cheques has fallen by about $69 \%$ for same period from 29.167 million transactions in 2009 to 9.019 million transactions in 2018.

From the above, it is quite obvious that the adoption of electronic banking is increasing while a the non-electronic system (cheque book) is decreasing. With the adoption of electronic banking have come benefits both for the banking institutions and bank customers. As noted by Abaenewe, Ogbulu and Ndugbu, (2013) the automation of banking transaction has improved data processing and accessibility for quick management decision making. Thus leading to reduction in operating costs and improving the potential to track fraudulent transactions. Okifo and Igbunu (2015) asserted that electronic banking has reduced transaction costs and improved speed of completing transaction. Electronic banking has also reduced the incidences of robbery occasioned by the need for businesses and individuals have to hold large amounts of cash which is a target of armed robbers.

From the above, it would be easy to conclude that the adoption and implementation of electronic banking methods has greatly improved banking operations in Nigeria both for the banking institutions and banking customers. However, what is not clear is whether the improvement occasioned by the adoption of electronic bank has had any effect of performance of banks in terms of growth in assets. This is considering the fact that the implementation of electronic 
banking comes at huge cost to the banks in terms of manpower, equipment and introduction of new process. Thus, this paper is aimed at assessing the effect of the adoption of electronic banking on the assets base of banks in Nigeria.

\section{A. Research Problems}

The implementation of electronic banking comes with numerous problems which may make it challenging for the concerned banks to implement. The most critical of these challenges is that infrastructure. Implementing a seamless electronic banking requires the installation of hitech information and communication technology infrastructure which requires huge cash outlay. Furthermore, electronic banking requires uninterrupted electricity supply and for the most part, this has become an intractable problem in Nigeria. Another problem associated with its implementation is the low internet penetration in the country especially in the rural areas (Ovia, 2005). Abaenewe et. al, (2013) also identified some of the problems of implementing electronic banking in Nigeria to include increase in internet fraud, high maintenance costs for equipment, low literacy level among the populace and manpower requirements.

In the course of the review of literature, several research works dealing on the subject matter were identified. However, only Oladejo, (2016); Obiekwe \& Anyanwaokoro, (2017); Abaenewe et. al, (2013); Oyewole, Abba, Gambo \& Abam (2013) assessed electronic banking in terms of its performance with respect to ROA, ROE and profitability. Others like Tijani and Ilugbemi, (2015); Oyewole, Gambo, Abba and Onuh (2013) researched on its effect on the economy. Okifo and Igbunu (2015); Adeyelure, Pretorius and Kalema (2014) investigated the challenges of electronic banking adoption in Nigeria. In all no previous research has assessed the effect of electronic banking on the asset base of commercial bank in Nigeria. The present study aims at filling this gap in research.

\section{B. Purpose of the Study}

The purpose of this research is to determine the effect of the implementation of electronic payment systems on the performance of commercial banks in Nigeria. The specific objectives of the research are as follows:

- Determine the effect of Automated Teller Machines (ATMs) transactions on the performance of commercial banks in Nigeria

- Determine the effect of Point of Sales (POS) Machine transactions on the performance of commercial banks in Nigeria

- $\quad$ Determine the effect of Internet (online) Banking transactions on the performance of commercial banks in Nigeria

Determine the effect of Mobile Phone Banking transactions on the performance of commercial banks in Nigeria

\section{Hypotheses}

Ho1: $\quad$ Automated Teller Machines (ATMs) transactions do not significantly affect the performance of commercial banks in Nigeria

Ho2: Point of Sales (POS) Machine transactions do not significantly affect the performance of commercial banks in Nigeria

Ho3: Internet (online) Banking transactions do not significantly affect the performance of commercial banks in Nigeria

Ho4: Mobile Phone Banking transactions do not significantly affect the performance of commercial banks in Nigeria

\section{ELECTRONIC PAymENT System}

Payment systems involves the operational network governed by laws, rules and standards which connects bank accounts and provides the necessary functionality of monetary exchange using bank deposits. It is the infrastructure comprising of institutions, organizations, instruments, rules, standards, procedures and technical processes established to make possible the transfer of monetary value between different parties discharging agreed obligations (Massimo \& Gracia, 2008; Summers, 2012). Harelimana, (2018) defined Electronic payment system as a form of inter-organizational information system for monetary exchange, linking many organizations and individual users. This may require complex interactions between the stakeholders, the technology and the environment. Payment systems can be physical using tradition methods or electronic (virtual) using information and communication systems to deliver the necessary services.

Thus, electronic payment systems are the information communication technology based systems established to facilitate the monetary transactions between parties using bank based platforms. In Nigeria, the operational electronic payment systems include Automated Teller Machines (ATMs) Point of Sales (POS) machines, Mobile Banking and Internet (Online) Banking Platforms. The last two options promise more convenience and wider use as the services can be assessed on electronic devices owned by the individual customers.

Electronic payment systems boast of certain benefits over their physical counterparts. First is the speed of completing transactions the distance between parties notwithstanding. Another benefit is that of convenience as parties can conduct financial transactions from the convenience of their bed or even the bathroom. Again, electronic payment systems can handle much larger volumes of transactions given the same time allocation than the physical payment systems. Furthermore, financial transactions through electronic systems are easier to track making transaction easier to audit and monitor such transactions for fraud or management decision making. Given these benefits, banking institutions can benefit immensely from establishing electronic systems as a viable replacement for the traditional payment systems.

According to Okifo and Igbunu, (2015) electronic payment systems in addition to their convenience and safety also have a significant number of economic benefits which 
include mobilizing savings and ensuring most of the cash available in the country are with banks. Thus, by being convenient and cheap to operate, electronic payment systems have the potential to improve financial inclusion and deepening for a developing country like Nigeria where savings mobilization remains a problem.

\section{EMPIRICAL REVIEW}

Obiekwe and Anyanwaokoro (2017) investigated the effect of Electronic payment Methods on the profitability of commercial banks in Nigeria. Using a sample of five banks for which data was collected from central bank of Nigeria statistical bulletin and analyzed using Panel Least Squares estimation technique analytical tool. Findings revealed that Automated Teller Machine (ATM) and Mobile Phone payment have significant effect on the profitability of commercial banks in Nigeria. However, Point of Sale (POS) has an insignificant effect on commercial banks' profitability in Nigeria. The study thus recommended that commercial banks should sponsor media campaigns in order to boost the awareness on Automated Teller Machine (ATM) payment and Mobile Phone payment methods so as to further increase their profitability.

Oladejo, M. (2016) focused on the impact of ATM, POS, web/Internet and mobile e-payments adoption on banks' profitability in Nigerian. Secondary data were obtained from annual report and accounts of ten commercial banks for the period 2005 to 2012 and were analysed using panel logistic regression. The results showed that when bank adopt epayment systems, their performance level, such as gross margin, profits after tax, return on assets and return on equity changes. This is reflected in the positive association between adoption and gross earning of banks. Further, adoption of the four e-payment instruments like ATM, WEB, POS and Mobile banking influenced performance indices measured by return on assets, gross margin and profits after tax of the sampled banks.

Tijani and Ilugbemi (2015) examined the impact of electronic payments channels on economic development of Nigeria. Data for the study was collected by sampling the opinion of a sample 98 current and savings accounts holder of six commercial banks in Ekiti state. The data was analyzed using inferential statistics specifically with the use of chi-square. The results revealed that electronic payment channels had impacted on the economy and therefore contributing positively to national development.

Okifo and Igbunu (2015) investigated the economic benefits and challenges of adoption of electronic payment system in Nigeria. The study concluded that though epayment is faced with challenges, like public acceptability, lack of uniform platform being, operated by the banks, lack of adequate infrastructure and issues of security however, with the proper use of e-payment system, corruption which is a cancer in government arena will be holistically addressed.

Adeyelure, Pretorius and Kalema (2014) carried out an investigation on electronic payment system in Nigeria with a focus on the implementation and constraints using a sample of 200 respondents while analysis was carried out predominantly on the primary data retrieved from the respondents. Militating constraints towards success of the system were identified in the study and also suggested recommendations for effective implementation of the system. The findings of the research showed that regulatory framework and policies should be introduced by government that will help in consolidating e-payment systems through suitable regulations.

Abaenewe, Ogbulu and Ndugbu (2013) investigated the profitability performance of Nigerian banks following the full adoption of electronic banking system in the country. The study used data from four banks that consistently retained their brand names within the study. They tested the pre- and post-adoption of e-banking performance difference between means using a standard statistical technique for independent and that the adoption of electronic banking has positively and significantly improved the returns on equity of Nigerian banks. On the other hand, it also revealed that ebanking has not significantly improved the returns on assets of Nigerian banks.

Oyewole, Gambo, Abba and Onuh (2013) explored relationship between e-payment system and economic growth as means of reviewing current transition to cashless economy in Nigeria. Data was analysed using OLS and TSLS methods covering period of seven years from 20052012. The result indicated a significant positive relationship between e-payment system and economic growth in term of real GDP per capita and trade per capita. Only ATMs was found to positively contribute to economic growth while other e-payment channels contribute negatively. Hence they recommended thatcurrent cashless policy should be tailored towards effective e-payment system and other factors which bear much relevance on successful transition to cashless economy should be prioritized.

Oyewole, Abba, Gambo and Abam (2013) examined the impact of electronic banking on banks' performance in Nigeria using panel data from annual audited financial statements of eight banks that have adopted e-banking and retained their brand name banking between 2000 and 2010 as well as macroeconomic control variables were employed to investigate the impact of e-banking on return on asset, return on equity and net interest margin. Findings revealed that e-banking begins to contribute positively to bank performance in terms of return on assets and net interest margin with a time lag of two years while a negative impact was observed in the first year of adoption. It was thus recommended that investment decision on electronic banking should be rational so as to justify cost and revenue implications on bank performance.

\section{Methodology}

The ex post facto research design was adopted for the purpose of this study. The design was adopted considering the nature study which require the collection of data on events that had already taken place. Data for the study was collected mainly from the Central Bank of Nigeria (CBN) statistical bulletin 2019 edition. Data collected were those on commercial banks transactions via electronic channels including Automated Teller Machines (ATMs) Point of Sales (POS) machines, Internet (Online) Banking and Mobile Banking channels and the performance of commercial banks which was measured using the Aggregated Asset Base of the commercial banks in Nigeria. 
Method of analysis adopted for the study is the Ordinary Least Square (OLS) regression technique. In its general form, it is given as:

$$
\begin{aligned}
& \mathrm{Y}=\mathrm{B} 0+\mathrm{B} 1 \mathrm{X} 1+\mathrm{B} 2 \mathrm{X} 2+\ldots .+\mathrm{BNXN}+\mathrm{U} \ldots \ldots(1) \\
& \text { Where } \quad \mathrm{Y}=\text { Dependent Variable } \\
& \mathrm{X} 1 \ldots . \mathrm{XN}=\text { Independent Variables } \\
& \mathrm{B} 1 \ldots . \mathrm{BN}=\text { Coefficients of independent variables } \\
& \mathrm{B} 0=\text { Constant Term } \\
& \mathrm{U}=\text { Error Term }
\end{aligned}
$$

For the purpose of the study, it is posited that commercial banks' performance of banks measured as the size of the asset base (ASSETS) is a functions of the implementation of electronic banking measured as: Automated Teller Machines Transactions (ATMTRA); Point of Sales Transactions (POSTRA); Internet Banking (INTBNK) and Mobile Banking (MOBBNK). This is stated functionally as:

ASSETS $=\mathrm{f}($ ATMTRA, POSTRA, INTBNK, MOBBNK) .... (2)

The above is restated econometrically as:

ASSETS $=\mathrm{B} 0+$ B1ATMTRA + B2POSTRA + $\mathrm{B} 3 \mathrm{INTBNK}+\mathrm{B} 4 \mathrm{MOBBNK}+\mathrm{U} \ldots$. . (3)

It is expected that $\mathrm{B} 1, \mathrm{~B} 2, \mathrm{~B} 3, \mathrm{~B} 4>0$

\section{RESUlTS AND DISCUSSION}

Data for the research was collected from the 2019 edition of the Central Bank of Nigeria Statistical Bulletin and consists of data on Commercial Banks' Assets Base, Automated Teller Machines (ATM) transactions, Point of Sales (POS) transactions, Internet Banking (Web Pay) transactions and Mobile banking transactions for the period 2009 to 2019.

\begin{tabular}{cccccr}
\multicolumn{5}{c}{ TABLE I: RESEARCH DATA } \\
\hline & $\begin{array}{c}\text { Asset Base } \\
\text { (N'B) }\end{array}$ & $\begin{array}{c}\text { ATM } \\
\left(\mathbf{N}^{\prime} \mathbf{B}\right)\end{array}$ & $\begin{array}{c}\text { POS } \\
\left(\mathbf{N}^{\prime} \mathbf{B}\right)\end{array}$ & $\begin{array}{c}\text { WEB } \\
\text { PAY } \\
(\mathbf{N} \text { 'B) }\end{array}$ & $\begin{array}{c}\text { MOBILE } \\
\text { PAY (N'B) }\end{array}$ \\
\hline 2009 & 17522.858 & 548.600 & 11.030 & 84.150 & 1.270 \\
2010 & 17331.559 & 399.710 & 12.720 & 25.050 & 6.650 \\
2011 & 19396.634 & 1561.740 & 31.020 & 59.610 & 18.980 \\
2012 & 21288.144 & 1984.659 & 48.008 & 31.567 & 31.509 \\
2013 & 24301.214 & 2828.939 & 161.016 & 47.316 & 142.797 \\
2014 & 27526.416 & 3679.878 & 312.072 & 74.044 & 346.467 \\
2015 & 28173.261 & 3970.252 & 448.513 & 91.581 & 442.354 \\
2016 & 31682.824 & 4988.133 & 758.997 & 132.360 & 756.897 \\
2017 & 34593.889 & 6437.592 & 1409.813 & 184.597 & 1101.999 \\
2018 & 37206.989 & 6480.086 & 2383.109 & 404.601 & 1830.701 \\
\hline Source: Central Bank Nigeria (CBN) Statistical Bulletin, 2019 &
\end{tabular}

The regression results in Table 2 shows that there is a statistically significant positive relationship between ATM transactions and the assets base of commercial banks in Nigeria. This result implies that increased use of ATMs will lead to increase in the asset base of banks. Furthermore, the result indicates that there is a positive and statistically significant relationship between mobile banking transactions and the assets base of commercial banks. However, Point of Sales (POS) transactions had a negative and statistically relationship with the asset base of commercial banks in Nigeria. Internet (online) banking transactions had a positive relationship with the asset base of commercial banks. This finding implies that increase in the implementation of internet banking will lead to increase in the assets base of commercial banks. However, the result is not statistically significant indicating that the effect of internet banking on the asset base of banks in minimal.

\section{DISCUSSION OF FINDINGS}

This research paper investigated the effect of electronic payment systems on the performance of commercial banks in Nigeria. For the purpose pf the study, data was collected from secondary sources specifically from the CBN statistical bulletin and comprised of data on the assets base of commercial banks and internet banking (ATM, POS, Internet banking and Mobile banking) for the period of 2009 to 2019. The collected data was analyzed using ordinary least square (OLS) regression technique.

Findings of the research showed that there is a statistically significant positive relationship between ATM transactions and the assets base of commercial banks in Nigeria. This result implies that increased use of ATMs will lead to increase in the asset base of banks. However, Point of Sales (POS) transactions had a negative and statistically relationship with the asset base of commercial banks in Nigeria. These findings point to the fact that increased implementation of electronic payment systems in terms of 
ATMs will lead to increase in the assets base of commercial banks in Nigeria. However, has a deteriorating effect on the commercial banks' assets base. In a similar study, Obiekwe and Anyanwaokoro (2017) who investigated the effect of Electronic payment Methods on the profitability of commercial banks in Nigeria found that Automated Teller Machine (ATM) and Mobile Phone payment have significant effect on the profitability of commercial banks in Nigeria. However, Point of Sale (POS) has an insignificant effect on commercial banks' profitability in Nigeria.

The findings also showed that Internet (online) banking transactions had a positive relationship with the asset base of commercial banks. This finding implies that increase in the implementation of internet banking will lead to increase in the assets base of commercial banks. However, the result is not statistically significant indicating that the effect of internet banking on the asset base of banks in minimal. Finally, there is a positive and statistically significant relationship between mobile banking transactions and the assets base of commercial banks. Oladejo, (2016) who focused on the impact of ATM, POS, web/Internet and mobile e-payments adoption on banks' profitability found that when bank adopt e-payment systems, their performance level, such as gross margin, profits after tax, return on assets and return on equity changes. Abaenewe, Ogbulu and Ndugbu (2013) tested the pre- and post-adoption of ebanking performance difference and concluded that the adoption of electronic banking has positively and significantly improved the returns on equity of Nigerian banks. On the other hand, it also revealed that e-banking has not significantly improved the returns on assets of Nigerian banks.

\section{CONCLUSION AND RECOMMENDATIONS}

From the findings of the study, we conclude that the implementation of electronic payment system in Nigerian banks have had mixed effect on the performance of banks. Thus, while ATM, internet banking and mobile banking leads to improvements in the performance of banks, same cannot be said for point of sales machines which has a negative effect on bank performance. We also conclude that from the trends in electronic banking transactions, the use of electronic payment system will continue to grow in the country. Based on the above, it is recommended that commercial banks increase investments in the implementation of electronic payment system. It is further concluded that banks strengthen their internet banking security architecture to reduce the level of fraud inherent in electronic banking systems and also reduce fraud. Finally, it is recommended that the government improve on internet infrastructure in order to capture the rural areas in order to promote financial inclusion through electronic banking in the country.

\section{REFERENCES}

Abaenewe, Z.C., Ogbulu, O.M. \& Ndugbu, M.O. (2013). Electronic banking and bank performance in Nigeria, West African Journal of Industrial \& Academic Research, 6(1): 171-187.

Adeyelure, T.S., Pretorius, P. \& Kalema, B.M. (2014). E-payment system in Nigeria: success militating factors, International Journal of Advanced Computer Research, 4(1)14: 231-235.

Harelimana, J.B. (2018). The Role of electronic payment system on the financial performance of financial institutions in Rwanda, Global Journal of Management and Business Research: Finance, 18(1)1.

Kelvin, O. (2012). Mobile money for financial inclusion. Journal of Macro Finance, Africa 4(14).

Massimo, C. \& Gracia, J.A. (2008). Measuring payment system development. The World Bank Research Centre.

Obiekwe, C.J. \& Anyanwaokoro, M. (2017). electronic payment methods and profitability of banking firms in Nigeria: a panel data analysis, International Journal of Finance and Accounting, 6(3): 67-74.

Okifo, J. \& Igbunu, R. (2015). Electronic payment system in Nigeria: its economic benefits and challenges, Journal of Education and Practice. 6(16): 56-63.

Oladejo, M. (2016). E-payments adoption and profitability performance of deposits money banks in Nigeria, International Journal of Information Technology, 4(3).

Ovia, J. (2005). Enhancing the efficiency of the Nigerian payments system, Central Bank of Nigeria Policy Research, 29(1): 8-20.

Oyewole, O.S., Gambo, E.J., Abba, M. \& Onuh, M.E. (2013). Electronic payment system and economic growth: a review of transition to cashless economy in Nigeria, International Journal of Scientific Engineering and Technology, 2(9): 913-918

Oyewole, O.S., Abba, M., Gambo, E.J. \& Abam, A.I. (2013). E-banking and Bank Performance: Evidence from Nigeria, International Journal of Scientific Engineering and Technology, 2(8): 766-771.

Summers, B.J. (2012). Payment systems-design, governance and oversight, London: Central Banking Publications.

Tijani, J.A. \& Ilugbemi, A.O. (2015). Electronic payment channels in the Nigeria banking sector and its impacts on national development, Asian Economic and Financial Review, 5(3): 521-531. 